\title{
PRIVATISATION OF SOUTH AFRICAN HEALTH CARE: IN WHOSE INTEREST?
}

\author{
H.C.J. van Rensburg, A. Fourie
}

\section{INTRODUCTION}

Privatisation has today become a domestic term which is both officially and colloquially in frequent use. Health care is but one of several areas which has in recent times been increasingly subjected to the prominence of this concept and strategy. Both as a way of thinking and as a policy measure privatisation is uncritically accepted by South Africans as accomplished fact. The latty as well as alth care professionals have accepted privatisation as a welcome strategy in coping with many of the acute problems in the sphere of health care. In this manner it is indeed presented to us - and without reflection we buy the idea of the privatisation of health care, and simultaneously the justification thereof for the South African context.

We are sceptical of privatisation, especially regarding health care. Our scepticism originates in the narrowness of perspective, lamentable contradictions and preferences, and insensitivity as to the consequences of privatisation for particular people and groups -- all which are frequently evident in pleas for and justifications of this policy.

These are the kind of issues we would like to address. We would like to analyse privatisation as a social phenomenon, explicate the nature, the many

nifestations and nuances, and the pros $J$ cons thereof. Also we would like to question the seemingly evident concerning this phenomenon, take a critical stance towards the hidden interests and contradictions underlying it, dismantle its latent consequences, and weigh privatisation as a specific strategy of health care delivery against the prevailing problems on the South African health care scene. In short, we would like to evaluate the privatisation of health care in terms of its moral and practical justification in contemporary South African circumstances.

\section{PRIVATISATION: A DEFINITION AND CLARIFICATION OF THE CONCEPT}

A formal definition: Privatisation represents the introduction or further extention of market principles in the public social services ... (It) may be said to take place when responsibility for a service or a particular aspect of service delivery passes, wholely or in part, to the private sector and when market criteria, such as profit

\section{Abstract}

In this article, essentially a critique on the privatisation of health care delivery in South Africa, the concept and social phenomenon of privatisation is analysed and evaluated, and the detrimental side-effects and latent consequences thereof dismantled. It is argued that the privatisation of South African health care is a reflection of narrow economistic thinking that will neither contribute to the more efficient functioning of the existing health care system nor alleviate the prevailing problems of shortages of resources and deficiencies in organisation. Privatisation of South African health care is in the last instance and in many respectse not in the interest of the patient population in all its diversity.

\section{Abstrak}

In hierdie artikel word die privatisering van gesondheidsvoorsiening in SuidAfrika krities ontleed. Privatisering as konsep en sosiale verskynsel word eerstens geanaliseer en geëvalueer, warna die nadelige en latente gevolge en newe-effekte daarvan onthul word. Daar word geredeneer dat die privatisering van gesondheidsorg in Suid-Afrika ' $n$ weerspieëling van bekrompe ekonomiese denke is en nie sal bydra tot die meer effektiewe funksionering van die bestaande gesondheidsorgsisteem nie en ook nie die heersende probleme van die tekort aan hulpbronne en tekortkominge in organisasie sal verlig of oorkom nie. Die privatisering van gesondheidsorg in Suid-Afrika is in die laaste instansie en in vele opsigte nie in belang van die diverse pasiëntepopulasie nie.

and ability to pay, are used to ration or distribute benefits and services (Walker 1984 , p. 25). In this definition three core principles regarding the nature of privatisation come to the fore. Firstly, the process of privatisation can evolve gradually; secondly, privatisation can manifest itself proportionally; thirdly, privatisation refers to those complementary actions of transfer of responsibility and implementation of market criteria.

As will become clearer eventually, privatisation is not as simple and monolithic a concept and phenomenon as is sometimes professed. As an idea, an option of policy and even political and ideological symbol it turns out to be richer in content and more varied in meaning. In general, privatisation always involve a transfer from the public to the private sector. However, what is being transferred in this process and how it is transferred, to what extent and to whom and with which objectives and consequences this transfer occurs, have turned out to be contentious matters.

Privatisation is applicable to all public services, though certain sectors are more privatisation-prone than others. A view of the health sector likewise reveals certain sub-sectors or levels which are more privatisation-prone than others, some of which have known a longer history of privatisation. In this regard it is important to note that it is not only the formal sector of health care which is involved in privatisation. Also the quasi-formal (voluntary services, charitable organisations and self-help groups) and informal (family, neighbourhood and friendship groups) sectors deliver health services on a private basis and are frequently part of privatisation actions even though the profit-motive and market criteria do not apply to these sectors.

The components of health care involved in privatisation are likewise divergent. It is possible to privatise all those components or activities of health care in which the state has a share or for which the state takes responsibility. As such, privatisation can be directed at

- the provision of health care, i.e. privatisation of commodities provided by the state, institutions owned and managed by the state, and personnel employed by the state;

- the financing of health care, i.e. privatisation of the funding of commodities which is presently subsidised or provided free of charge by the state;

- the regulation of health care, i.e. privatisation of areas in which the state controls the provision of a commodity, its quantity, quality and price.

The fact is that privatisation not only entails a narrow economic process whereby material ownership, facilities and financing are being transferred from the state to the private sector. It also involves a political and social dimension in that power, control, responsibility and management are passed onto the private sector. 
Privatisation can thus take on many forms. A simplistic interpretation as though privatisation means the mere replacement of the state by the market is not sufficient. Both the type of state intervention to be replaced and the type of non-state institution which is to replace the state, must be specified. With these guidelines in mind, Le Grand and Robinson (1984, p. 6) differentiate three forms of privatisation according to the type of state intervention which privatisation is to reduce or eliminate, namely:

- reduction in state provision (e.g. by way of private hospitals, private practitioners);

- reduction in state subsidy (e.g. by way of co-payments and self-financing);

- reduction in state regulation (e.g. the lifting of restrictions).

Furthermore, these authors differentiate three forms of privatisation on the basis of the type of activity which is proposed instead of the state, namely:

- replacement of the state by the market and profit-maximising entrepreneurs (e.g. in the production of medicine);

- replacement of one form of state activity by another (e.g. provision by regulation);

- encouragement of activities and organisations that are neither the conventional profit-maximising firm nor the state enterprise (e.g. charitable organisations and consumer co-operatives)

More specifically, privatisation is an umbrella term for a wide variety of concrete measures or mechanisms including: contracting out, competitive tendering, partnerships or agreements between the state and private entrepreneurs, monopoly concessions, management contracts, vouchers, the selling or leasing of state enterprise and assets, shareholding, encouragement or establishment of voluntary organisations, curtailment of state subsidies, cost sharing, reintroducing the fee-for-service model, reduction or phasing out of certain public services, etc. All these, and more, represent concrete manifestations of privatisation, on condition that the responsibility of either provision, financing or regulation of the particular public service in all these cases are shifted as a whole or in part from the public to the private sector. At all times privatisation involves the withdrawal of state responsibility and the establishment and expansion of capitalistic enterprise and individual self-help. (Cf. Abramovitz 1986; Ascher 1987; Consolidated Report 1986; Croeser 1984; Heald 1985; Heald \& Morris 1984; Republic of South Africa 1987; Spier 1987).

\section{THE MOTIVATION, OBJECTIVES, HIDDEN VALUES AND INTERESTS UNDERLYING PRIVATISATION}

Obviously the motivation, rationale and objectives behind privatisation vary according to the particular sector and form of privatisation, as well as the specific measures and mechanisms of privatisation. Broadly speaking, any privatisation action in the first place implies a reformulation of the relation between the private and public sectors in society in general or in certain sectors only. Specifically privatisation is aimed at the scaling down of the public sector in order to, on the one hand, reduce the welfare activities of the state and, on the other hand, to increase the efficiency of the public sector (Walker 1984, pp. 29-30). Privatisation originates, therefore, from the supposed deficiencies of the different forms of state-involvement and the accompanying belief in the ability of private enterprise to overcome these deficiencies. Says Walker (1984, p. 31): $\boldsymbol{A t}$ the heart of the privatisation policy, is the assumption that the public sector is wasteful, inefficient and unproductive ... a burden on the economy ... and further: For the defects are real. They include unnecessary slipshod and wasteful management, and poor quality service. undisciplined by competition or by any other procedures for ensuring accountability to the customers. Too often co-ordination between different public services is poor and they show insufficient sensitivity to local needs and feelings. But, says Donnison (1984, p. 48): It is true that provision by the privale sector is often even worse, but to take refuge to that riposte is an evasion, not a remedy. In whatever way, privatisation can be related directly to the wave of fiscal conservatism and the rebellion against 'big government' (Ascher 1987, p. 3)

The specific objectives (and thus advantages) of privatisation are highly diverse (Ascher 1987; Consolidated Report 1986; Heald 1985; Heald \& Morris 1984;

Le Grand \& Robinson 1984; Van Niekerk 1986; Vann 1987; Walker 1984; Republic of South Africa 1987). In the first place it entails financial-economic considerations, among which: accomplishing costeffectiveness, effective utilisation of scarce resources and the optimal operation of market forces, stimulation of additional economic opportunities and incentives for higher productivity and saving, relief of inflationary pressure and tax, encouragement of small-business growth, increase of the nett fixed investment in the private sector, reduction of state intervention in the economy and curtailment of administrative expenditure, and creating additional resources of revenue. In addition, this time on a political-administrative level, privatisation contemplates greater effectiveness in the provision, distribution and organisation of services; it attempts to neutralise or reduce the scale of collective bargaining, demands and confrontations, to limit burgeoning bureaucracies, to counteract dependency on the state, to stimulate self-reliance, and to depoliticise decisions concerning the allocation of scarce resources by subjecting it to market forces. All these general motives, objectives and advantages of privatisation can be applied to the privatisation of the health care sector as well.

However, a substantial part of the highly appraised rationale and advantages of privatisation is rather make-believe justifications which are not sufficiently substantiated by scientific proof. Some of the fallacies surrounding the propagation of privatisation are: that the free market is always more efficient; that private provision is more cost-effective; that privatisation will thus enhance efficiency and reduce consumer costs; that the private market is a superior mechanism of allocation; that it ensures better quality and that the private sector can completely replace the public sector (Cf. Le Grand \& Robinson 1984; Maynard \& Williams 1984: Walker 1984). Moreover, the few studies which have been undertaken in this regard fail to substantiate these myths (Ascher 1987, pp. 15-18; Le Grand \& Robinson 1984, p. 9). Fact remains that there is no substantive proof whatsoever that private and public provision make any difference either to the quality of service or to its efficiency. Neither is there proof of significant private superiority.

\subsection{The hidden values and interests in} privatisation

The above-mentioned fallacies already suggest that there is more to the idea of privatisation than the discernible.

Economic, political and ideological values, interests and motives are inherently part of privatisation or are from time to time ascribed to it. It is therefore necessary, especially with regard to the strong conviction with which this strategy is today propagated, to reflect critically on the following questions: In whose interest is privatisation? Or, which interest groups are behind privatisation? At whose expense is privatisation implemented? And, which manifest and latent consequences ensue from privatisation?

With reference to the political, economic and ideological dimensions of privatisation it is essential to grasp the direct relation between privatisation and capitalism, capitalistic principles and capital inte Implicit in the privatisation idea is the high estimation of entrepreneurialism, individualism, market-justice, economic efficiency and the idea of health care as a trade (Beauchamp 1979; Donnison 1984; Kurtz \& Chalfant 1984; Maynard \& Williams 1984; Roemer 1977, 1980; Van Rensburg 1985; Walker 1984). According to these principles social problems (including disease and illness) are regarded as personal matters, the causes of which are to be explained in terms of individual fault. In accordance with capitalistic principles health care services and facilities are commodities bought and sold on the free market and for purposes of maximising profit. In combination these principles imply that health care is mainly available to those in a position to afford and with the means to pay for it.

Suffice it to say that privatisation, on account of its firm links with capitalism, entails the danger of commercialising health care; what is to be a humane enterprise is thus transformed into a frigid trade. The inherent danger to economistic 
thought on health care (so strikingly present in the idea of privatisation) is that commercial efficiency is identified with the effectiveness of the system as a whole; that health policy can become a mere supplement of economic policy; that market relations and the price mechanism can be reified at the expense of distribution on the basis of real need; that the economic objectives of profit maximisation and economic growth can displace the social objectives of health care, or that social objectives can be subjected to economic ones and to an overall economic hegemony (Walker 1984).

With this in mind it is clear that the privatisation of health care is not only directed at creating a new balance between the public and the private sector. It also encompasses a restructuring and transformation in the character of existing health care systems, especially with regard to fmancing and organisation, as well as to the prevailing power relations, accentuations and order of priorities. ose interests will ultimately be served $\overline{\text { by }}$ privatisation and at whose expense? these are questions the answers of which can already be anticipated.

\section{PRIVATISATION OF SOUTH AFRICAN HEALTH CARE}

Privatisation is a phenomenon which currently manifests itself especially in those countries with mixed economies; that is, where the need is to establish an appropriate balance between the private and public sectors. According to Roth (1987, p. vii), the appropriate mix between public and private sector activities vary from society to society. The nature and extent of privatisation in a particular country obviously depends on the prevailing proportional relation between public and private sectors; furthermore, on those internal and external forces which her promote or constrain privatisation. $p$ in mind, too, that the international debate on privatisation does not always take the same course. Moreover - as West (1984, p. 111) shows - the debate on privatisation is complicated by the extent to which it is either considered a separable issue or part of a wider social distribution of income and wealth.

In South Africa the privatisation phenomenon in itself and the privatisation of health care likewise, are in origin, content and manifestation at par with the rest of the world. Although privatisation of health care is not new to South Africa, it leaves no doubt that the total package of health services has become evermore socialised rather than privatised, that is, it has increasingly become state property, financed and controlled by the state. Moreover, it is true that government involvement has expanded dramatically during the past few decades. Nevertheless, the popular emphasis in thought indicates a shift in favour of privatisation. The consciousness of privatisation and deliberate propagation and implementation thereof in South African health care is a phenomenon of the 1980's.
The motivation and specific reasons underlying privatisation in South African health care are, as elsewhere, directly related to economic and financial circumstances that deeply affect the health care system. (Cf. Browne Report 1986; Republic of South Africa 1984, 1987; Spier 1987; Vann 1987; Van Niekerk 1986.) Firstly, the already excessive and imminent increase in state expenditure on health care, met by determined government attempts to contain and reduce expenditure.

Secondly, and in combination with the first, the extensive involvement of the public sector in the economy is seen to be undesirable and should rather be scaled down in order to effect economic development and growth. In short, privatisation is directly motivated by reducing both state expenditure and public sector involvement. More specific reasons presented for the privatisation of South African health care are rising state expenditure, the cost spiral, unfavourable exchange rate for imports, rising needs and demands for quantity and quality in health care, the inflation rate, social and political uncertainties, and the availability of medical schemes. Obviously the rationale and motivation for privatisation in the last instance appear to be overpowering economic considerations, economic demands and economic problems. The prevalent rationale and urgency behind privatisation are based in the main on economic-financial analyses and justifications; one is even tempted to think that the proponents of privatisation are thinking exclusively in economic terms. If this should be the case sheer materialism and economic determinism are at stake.

The manner in which privatisation manifests itself in South Africa is equally divergent. From a supplier's point of view privatisation involves the transfer of responsibility for provision, financing and regulation of health care to private initiative and the arrangement thereof along market criteria. From a consumer's point of view it involves the transfer of costs and responsibility for health and care to the individual himself and a call for selfcare and voluntary services. More specifically, (according to the Browne Report 1986; Consolidated Report 1986; Van Niekerk 1986) the principles along which the privatisation of health care in South Africa are directed, boil down to the following:

- Health care is an individual responsibility and privilege.

- The responsibility of the state lies with the provision of public services for the truly indigent, that is the handicapped, the elderly and the underprivileged.

- The state subsidises the individual rather than to finance the institution.

- Services must as far as possible be rendered on an economic basis, that is, those who can pay, should pay.

- Effertive competition and a free market are encouraged and over-regulation is eliminated.

- Appropriate, cost-effective standards of health care are to be implemented, while the establishment of minimum standards which is beyond the financial ability of the country is to be avoided.

\section{THE ESSENCE OF SOUTH AFRICAN HEALTH CARE PROBLEMS}

The past few years have seen a boom in literature on South African health care. The prevailing health problems and the multiple facets thereof are defined, analysed and summarised in all meticulousness and sophistication (Benatar 1983; Benatar \& Kirsch 1987; Browne Report 1986; Consolidated Report 1986; De Beer 1984; De Villiers Report 1985; Kriel 1986; Mitchell 1985; Ross 1984; Savage 1979, 1986; Spier 1987; Van Rensburg 1982, 1985; Zwi \& Saunders 1985). In pace with the fashion of the day, scenarios for the future in this field are equally well-known. Certainly, there is no lack of definitions and analyses of the problem, even no lack of correct definitions and thorough analyses. However, the solutions and remedies prescribed are quite different. Often we are confronted with irreconciliable strategies which in the last instance stem from irreconcilable ideological, political and economic convictions and interests.

In this section we shall present a brief reconstruction of the most prominent problems on the South African health care scene. The aim is to ascertain to what extent the privatisation strategy would contribute or not to alleviating these problems. Our point of departure is that these problems can be deduced to two mutually-related core problems. These are, firstly, problems related to shortages of resources and, secondly, deficiencies in the organisation of available resources.

To a large extent the nature and origin of these problems can be understood and explained in terms of those strongly manifested structural characteristics which South African health care has developed over the years. Besides being strong impediments to real solutions, these structural characteristics also deepen the extent and intensity of the problems at hand. In this context the following can be illuminated:

- The strong emphasis on curative medicine and the accompanying disease-orientedness of the care system;

- the hospital-centred nature of health care accompanied by highly specialised, high-tech and experimental medicine;

- the strong focus in the supply of health care to the white population, securing them with a service more superior in quality and quantity relative to that of other populations groups;

- the one-sided allocation of resources in favour of the urban population with marked provisional deficiencies in the rural areas, especially the national and self-governing states;

- the weakly developed ancillary services in vital sectors of health care and the continuous scepticism towards the value of middle-grade workers;

- the marked impression which apartheid 
and white domination have left on the health care system with all the divisions and side-effects it has brought to health care;

- the domination of the care system by the medical profession and the accompanying physician-centered care;

- the principles of free market medicine permeating and sometimes dominating the health care system ideologically and in practice;

- the segmentation of South African health care in a multitude, sometimes competing and conflicting public and private authorities, of delivery systems and factions:

- the highly diverse socio-cultural and socio-economic composition of the clientele, confronting the care system with equally diverse demands, thus stressing the enormous problem of establishing priorities.

With reference to the two core problem areas in South African health care, we present the following synoptical reconstruction. In the first place, the problem of shortages of resources originates from limited financial means, limited manpower, the limited growth potential of these, the draining of manpower to other sectors and countries, and the escalating demands of the explosive population growth which is in striking discord with the provisioning abilities of our country. These are primary shortages. In contrast to these there are also secondary shortages referring to the maldistribution and malutilisation, even wasting of available manpower and material resources which is symptomatic of ineffective management of health care. More specifically secondary shortages include oversupply, overutilisation, and overconcentration of manpower, services and facilities in specific areas and for particular sectors of the population. Unfortunately these inevitably result in shortages of services and facilities for other sectors and in certain areas.

In the second place, problems concerning deficiencies in the organisation of resources, mainly relate to planning, control and co-ordination of the supply of care. In this regard South African health care is tragically divided along several lines and accordingly often operates uncoordinated and unintegrated, indeed as a result of many natural and man-made dividing lines, but also because of a striking lack of an overall, centrallyregulated and centrally-planned health care policy. Fact remains that South African health care is organised in such a way that secondary shortages, maldistribution, malutilisation, waste, overlapping, duplication and gaps are to be expected. This, despite the National Health Plan which has in idea and intention every potential of making a breakthrough, but unfortunately with meagre chance of success in practice due to several vested interests and interest groups with major differences in priority. The prevailing problem in South African health care today, is that of a highly pluralistic health care system having to cater for the diverse needs of a most complex society. To synchronise the already limited resources in a balanced and fair way with the real and abundant needs, clearly demands skill and wisdom. For that reason, central planning, central co-ordination and central control are more necessary and a relapse to a more laisse $\%$-faire policy certainly the undesired.

How and to what extend privatisation is an appropriate strategy in handling these problems of shortages and organisation, and also a sensible way of reforming the manifest structural characteristics in South African health care are questions to be addressed now. After all, the only relevant questions are: Will privatisation contribute to the advancement of health care in South Africa? Will it lead to a more equal provision? Will it distribute more equally, assure better utilisation, and be more sensitively attuned to needs? Will privatisation enhance accessibility, attainability and affordability? Will it ensure better planning and co-ordination? In short, does the privatisation option present a just and justifiable solution?

\section{PRIVATISATION OF SOUTH AFRICAN HEALTH CARE: A REJECTION ON MORAL AND RATIONAL GROUNDS}

In the first place the privatisation of South African Health care can certainly be judged from a moral point of view: Is it a just strategy? The question concerning the justice of privatisation of health care in South Africa is essentially an ethical one, a question referring to the treatment of the person, or to the degree to which this measure is in favour or to the expense of man's welfare (Heyns 1987). It is a question we in our capacity as scientists are somewhat reluctant to answer. However, being South African citizens with a sensitive social conscience and moral responsibility, we surely may address the unfair and unjust side-effects of privatisation, and distantiate ourselves in this regard from the following:

- The commercialisation of health and illness and the increasingly central position of the profit-motive in the allocation, accessibility and quality of health services.

- The entrustment of provision and distribution of health care to the random and socially-insensitive marketmechanism with its well-known reputation for exploitation of the ignorant.

- The narrowly defined, economic objectives which are automatically accepted as more legitimate than social objectives and whereby health care resources are distributed in accordance with economic rather than social priorities

- The deliberate creation and institution of a discriminating two-class system of health care where the affluent are favoured with a first-class service and quality, while the indigent as a result, must be satisfied with second-class services and quality with all the social costs implied.
- The decision-making monopoly of the political and economic power elite in the propagation and implementation of privatisation in health care with no participation from the greater part of the population and without a balanced consideration of the most urgent health needs.

- The real risk of deterioration in the supply situation and health status of the already deprived, as a result of the redistribution of resources for which privatisation is infamous.

- The inevitable aggravation of inequality and more fundamental distributional injustice following from privatisation of health care.

- The justification of privatisation on grounds of escalating state expenditure and too big a public sector, while at the same time costly, wasteful and monstrous structures are erected in the field of health care.

In the second place the privatisation of South African health care can be evaluated from a practical point of view; Is it a justifiable strategy? This question of the justification of privatisation as a policy measure in South African health care is essentially a rational one, a question about the conduciveness or injuriousness of privatisation for the efficiency and effectiveness of health care delivery. As medical sociologists we are indeed entitled to debate this question critically.

Rationally spoken, that is addressing the justification, the appropriateness and workability of the privatisation option, we are outspoken against or at least critically reserved towards the progressive privatisation of South African health care.

First of all the following general remarks:

According to the analysis of thought on privatisation and the problems it is supposed to solve, it is disturbing to realise that thought on health care matters is narrowly centered around economic principles and interests, that policy is likewise directed by economic priorities and guidelines, and that hope is mainly vested in simplistic solutions. Privatisation is one manifestation of this kind of thought. We shall argue that increasing privatisation will neither enhance the efficiency of organisation, nor effectively solve prevailing health problems. The reason is that privatisation departs from a simplistic, even incorrect definition of the core problems in South African health care. Consequently the symptoms of the problem, rather than the real problem and its underlying causes are addressed.

Differently stated: The protagonists of privatisation fixate on the problems of escalating costs, rising consumption and the excessive share of the public sector in health care; they propagate privatisation as the remedy. Certainly, no one can deny the reality of these problems. However, the motivation behind privatisation is not in the first place focused on effectiveness, quality and improvement of health care and the health status of the total population, but rather on financial arrangements, cost-containment and cost- 
effectiveness. Incorrectly, it identifies economic efficiency with administrative efficiency, and cost-effectiveness with effective handling of health problems. Our argument is: The core problems harrassing South African health care are problematic structural characteristics, shortages (especially secondary shortages) and deficiencies in organisation. Privatisation is not capable of solving these problems, it can rather aggravage several of them.

To be more specific:

- Firstly, with increasing privatisation we run the risk that several of the problematic structural characteristics of South African health care will manifest themselves even stronger. Privatisation is bound to stimulate expensive, luxurious and profit-maximising care and care structures; it will shift the emphasis still further in the direction of unaffordable high-tech, curative, experimental and specialised services and facilities, as well as to intramural care -- all at the expense of primary, prophylactic and preventive care. Privatisation is attuned to stimulating the free market system in health care, and naturally along with it all those side-effects of pluralism, of unequal provision and distribution of manpower and facilities, and of poaching the cream of the public sector. Privatisation will stimulate further extention of the present care system which primarily cater for the privileged, white and urban population. From this point of view, privatisation will have little impact in neutralising the problematic structural traits in South African health care; it will rather perpetuate and reinforce these traits.

- Secondly, with increasing privatisation we run the risk of stimulating and perpetuating the identified secondary shortages in health care. Privatisation will intensify or at least foster the relative oversupply, overconcentration and overutilisation of manpower and facilities in urban, white and affluent sectors of the population. It will also reinforce the malutilisation of manpower and facilities or further distort manpower and facilities in favour of highly specialised, costintensive, curative and experimental care, unfortunately to the detriment of the outspoken need for primary, preventive and promotive services which are in any case more affordable. From this point of view, we cannot envisage how privatisation will bring about cost-effectiveness and economic efficiency with regard to the total utilisation of the limited national resources and manpower; also we cannot foresee how the pressure of escalating state expenditure and a burgeoning public sector will be contained and scaled down while at the same time government proceeds in spending excessively on the erection of monstrous bureaucracies.

- Thirdly, with increasing privatisation the chances are good that nothing will be achieved as far as the above- mentioned deficiencies in organisation of health care are concerned; rather that corrections will become less achievable as a result of greater pluralism and segmentation, more divergent priorities, and stronger interest groups which result from privatisation. Along with increasing privatisation the supply of care is even more segmented, less centrally planned, and less coordinated. As a result the health care system becomes more inclined and susceptible to inequity and discrimination. All in all it becomes more difficult to reconcile the total supply of health care in a balanced and just way with the real needs of the total population. As far as privatisation is a risk to the further distortion of the supply-need relation, it must in present circumstances be seen as ineffective and unjustified. From this point of view, we cannot envisage how privatisation in any sensible way can contribute to the effective handling and solution of the real health care problems of the population and promote more effective goal attainment. Rather it will tend to strain organisation and render it less effective.

\section{CONCLUSION}

In conclusion - what is to be done? A wide-running elaboration on this question is not relevant to our theme. Our task was only to debate the phenomenon of privatisation and its justifiability and justification as a policy measure in addressing the problems on the health scene. Suffice it to say, privatisation and reprivatisation are not the long-expected and omnipotent remedies for curing the core problems in South African health care. One must rather go about cautiously and more discreetly with the idea of privatisation in health care. More so because it inherently entails many an injurious side-effect and can be at the expense of many groups and people in this country. After all, apart from financial costs, social costs are also real costs to account for, and apart from economic growth and efficiency, the social good is also a dear value to endeavour for.

\section{LITERATURE}

Abramovitz, M. 1986. "The privatisation of the welfare state: A review". Social work 31(4): 257-264.

Ascher, K. 1987. The Politics of Privatisation: Contracting out Public Services. London. MacMillan Education.

Beauchamp. D.E. 1979. "Public health as social justice" in Patients. Physicians and Illness. edited by E.G. Jaco. New York. The Free Press.

Benatar, S.R. 1983. "Some economic and philosophical dilemmas facing medicine in South Africa". South African Medical Journal 64: 768-77I

Benatar, S.R. \& R.E. Kirsch. 1987. "Baragwanath - a hospital in despair". South African Medical Journal 72: 307

Croeser, G. 1984. "Die privatisering van dienste in plaaslike bestuur". The South African Treasure October: 184-188.

De Beer, C. 1984. The Sourh African Disease:
Apartheid, Health and Health Services. Johannesburg. South African Research Service.

Donnison, D. 1984. "The progressive potential of privatisation". Pp. 45-57 in Privatisation and the Welfare State, edited by Le Grand, J. \& Robinson, R. London. George Allen \& Unwin.

Heald, D. 1985. "Will privatisation of public enterprise solve the problem of control?" Public Administration 63: 7-22.

Heald, D. \& G. Morris. 1984. "Why public sector unions are on the defensive". Personnel Management May: 30-34.

Heyns, J.A. 1987. "Wetenskap en Etiek". Occasional speech at the opening of the University of the Orange Free State. Bloemfontein. 6 February 1987.

Kriel. J. 1986. "Mediese beroep pleeg 'n onreg". Rapport 21 September 1986: 27.

Kurtz, R.H. \& H.P. Chalfant. 1984. The Sociology of Medicine and Illness. Boston Allyn and Bacon.

Le Grand, J. \& R. Robinson. 1984. "Privatisation and the welfare state: An introduction". Pp. 1-17 in Privatisation and the Welfare Siare, edited by Le Grand, J. \& R. Robinson. London. George Allen \& Unwin.

Maynard, A. \& A. Williams. 1984. "Privatisation and the National Health Service". Pp. 95-110 in Privatisation and the Welfare State, edited by Le Grand, J. \& R. Robinson. London. George Allen \& Unwin.

Mitchell, D. 1985. "Health and medicine in South Africa now and forty years on: A personal view". South African Journal of Science 18(13): 113-119.

Republic of South Africa. 1984. Verslag van die Komitee vir Ekonomiese Sake van die Presidentsraad oor Maatreëls wat heperkend inwerk op 'n Vrye-mark-georiënteerde Stelsel in Suider-Afrika. Cape Town. Government Printers.

Republic of South Africa. 1985. Verslag en Aanbevelings van die Komitee van Ondersoek na moontlike verdere fasiliteite van geneeskundige en tandheelkundige opleiding. (De Villiers-Report.)

Republic of South Africa RP 59-67/1986. Final Report of the Commission of Inquiry into Health Services. (Browne-report.)

Republic of South Africa. 1986. Consolidated report of the four working groups on privatisation and deregulation: Privatisation and Deregulation of Health Care in South Africa. Pretoria. Government Printers.

Republic of South Africa. 1986. Nasionale Gesondheidsplan. Pretoria. Government Printers.

Republic of South Africa. WPG/1987. Whire Paper on privatisation and deregulation in the Republic of South Africa. Pretoria. Government Printers.

Roemer, M.I. 1977. Comparative National Policies on Health Care. New York. Marcel Dekker.

Roemer, M.I. 1980. "Health services organisation and finance". Pp. 179-191 in Economics and Health Policy, edited by Griffiths, A. \& Z. Bankowski. Geneva. Council for International Organizations of Medical Services and the Sandoz Institute for Health Care and Socio-Economic Studies.

Ross, S.M. 1984. Health for all by the year 2000: Possibility or Pipe Dream? Inaugural Lecture. Durban. University of Natal.

Roth, G. 1987. The Private Provision of Public Services in Developing Countries. New York. Oxford University Press.

Savage, M. 1979. "The political economy of health in South Africa". Pp. 140-156 in Perspectives on the Health System in South Africa, edited by Westcott, G. \& F. Wilson. (s.l) (s.n). 
Spier, A. 1987. Towards Effective and Affordable Health Care in South Africa. Johannesburg. SYNCOM.

Vann, A. 1987. "Privatisation of Health Care". Hospital and Nursing Year Book of Southern Africa: $25-26$

Van Niekerk, W.A. 1986. "Privatisering moontlikhede en perke". SALUS 9(4): 8-9.

Van Rensburg, H.C.J. 1985. "Deur 'n alternatiewe sleutelgat: Kritiek op die vryemark-medisyne in Suid-Afrika". South African Journal for Sociology 16(1): 28-39.
Van Rensburg, H.C.J. \& A. Mans. 1982. Profile of Disease and Health Care in South Africa. Pretoria. H \& R Academica (Pty) Ltd.

Walker, A. 1984. "The political economy of privatisation". Pp. 19-44 in Privatisation and the Welfare State, edited by Le Grand, J. \&

R. Robinson. London. George Allen \& Unwin.

West, P.A. 1984. "Private health insurance". Pp 111-115 in Privatisation and the Welfare State, edited by Le Grand, J. \& R. Robinson. London. George Allen \& Unwin.
Zwi, A.B. \& L.D. Saunders, ed. 1985. Towards Healsh Care for All. Johannesburg. NAMDA.

Prof. van Rensburg is the head of the Department of Sociology at the University of the Orange Free State. Mrs Fourie is a lecturer/researcher at the same department. 